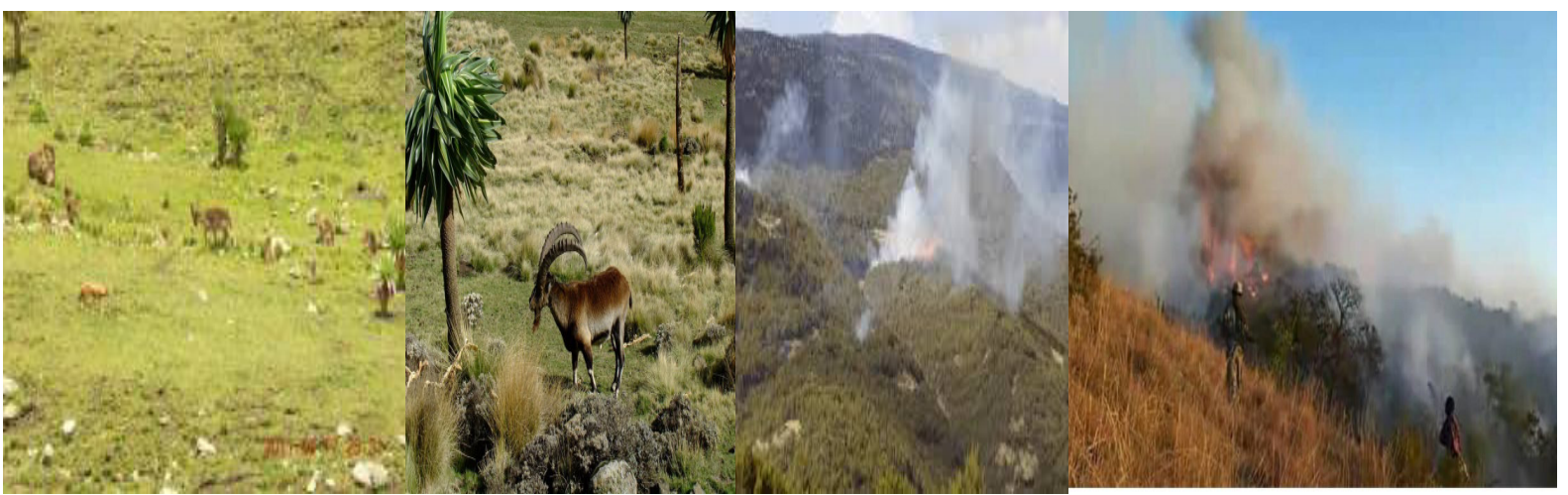

\title{
Fire Intimidations in Protected Areas and the Management Practices: Global Experience
}

\author{
Abdrahman Shafi \\ Department of Natural Resource Management, Wolkite University, College of Agriculture and Natural \\ Resources Management, P.O. Box 07, Wolkite, Ethiopia
}

\begin{abstract}
Today, protected areas face many threats mainly due to population growth and climate change. Management of protected areas assumes a vital priority to be given for the regulation of the ever changing global climate. However, conservation of these areas faces a challenge because of low consideration for biodiversity, cultural and historical values by local and national governments, local communities and NGOs. As a result, wildfires become a common phenomenon in different parts of the world creating serious disturbances leading to economical and societal problems, and loss of lives. Fire effect might not always be a problem: it can be a good tool or a bad visitor depending on how we deal with it. Fires and their impact have to be managed and should include social, economic, cultural and ecological variables with the aim of minimizing the damage and maximizing the benefits.
\end{abstract}

DOI: $10.7176 / \mathrm{JBAH} / 10-3-05$

Publication date: February $29^{\text {th }} 2020$

\section{Introduction}

Fires are the major disturbance of the Earth's ecosystems (Pausas and Kelley, 2009). Wildfires (uncontrolled fires) often pose important threats to public safety, properties, and forest resources. Fires are socially and economically unwanted disturbances of the ecosystems. They cannot be considered as a problem, they are global phenomena. Protected areas are created to protect biodiversity, and strict protection is often applied (Martell, 2007). Wildfires are observed in Europe creating serious disturbances in the society, and frequently they lead to economical and societal problems, and loss of lives, as observed in Portugal in 2003, Greece in 2009, and more recently in Russia (Rego et al., 2010). Protected areas are based on a myth that nature is separated from the people and nature is negatively affected when humans try to live on its resources. More than strict protection, these areas should be spaces of interaction between man, nature, and culture from a sustainable point of view and not areas where everything is forbidden (Pereira and Braga, 2009). Therefore, this paper review is aimed to understand the roles and effects of fire in protected areas and to identify the management of protected areas from fire.

\section{Importance of Management Plan and its Effectiveness in Protected Areas}

Currently, protected areas face many threats especially due to human expansion and climate change (Cole, 2008). Management of protected areas assumes a vital priority to be given for the regulation of human activities and adaptation to climate change (Nolte et al., 2010). Today, effectiveness of protected areas management faces a challenge because of low consideration for biodiversity, cultural and historical values by local and national governments, local communities, and NGOs (Hockings et al., 2006). The effective management of protected areas is widely recognized to be essential to its sustainability, and it is a fundamental tool at local, regional, and national levels.

Good management of protected areas needs to be based on a full and complete understanding of the areas, and it includes a regular monitoring and potential changes in its work. To ensure effective management for protected areas, identification of opportunities, threats, management gaps, potentials of the areas, and the role of stakeholders needs to be done. The second step is planning, which defines the objectives, vision, strategies to 
protect and conserve the area of interest, to reduce the threats and weaknesses, and to enhance the opportunities and the potential. Implementing the planned actions according to the process steps will produce the required outputs that result in (the intended goods and services (Dudley et al., 2008). Management effectiveness is achieved through good practices (Synge, 2004). These practices should be also based on the knowledge of local people. The contribution of local communities for the success of the protected area plan and management allows managers to avoid a large number of conflicts (Alexander, 2008).

\section{Fire in Protected Areas}

Historically, after the areas were declared to be protected, human activities are restricted to sustain ecological function and biodiversity protection. Among these measures the use of fire is forbidden in order to maintain pristine (original/untouched) conditions (Delong and Tanner, 1996). Wildfire is a common visitor of protected areas, leading to environmental degradation, including landscape destruction, soil erosion, nutrients depletion, biodiversity loss, ecosystems change (vegetation and habitats) and air pollution. These changes can remain to several years. The ecosystem recuperation (restoration) depends on the ecosystem vulnerability and resilience to this disturbance, topography, climatic conditions, and human intervention (McKenzie. 2010).

\section{Fire Impacts in protected areas}

Fire effect might not always be an environmental problem. Many of the ecosystems that we protect were actually influenced or created by fire. For example, grassland ecosystems around the world were strongly influenced by fire. Without the existence of fire, such ecosystems would be substituted by forests. Fire favors the spread of and the creation of numerous ecosystems that nowadays are considered to be key habitats for many species of herbs, grazing animals, butterflies, reptiles, and birds. Grasslands are the largest habitat in the world with an estimated area of 52.5 million $\mathrm{km}^{2}$ in the world or $40.5 \%$ of landmass (FAO, 2005).

\section{Community Participation in Integrated Forest Fire Management: Experiences from Europe, Asia and Africa}

There is a growing concern in the EU about protection of the natural areas with of view to avoiding the loss of biodiversity. In the last 25 years the EU has created a total of 26.000 protected areas with more than $750.000 \mathrm{~km}^{2}$ (Moya et al., 2011). In the EU the grasslands are habitats with great biodiversity. Nowadays, in the EU countries the grassland area decreased by $12.8 \%$ in the period of 1990-2003. Afforestation, intensive agriculture, and landuse change are the major responsible factors for this decrease (European Commission, 2008). Other ecosystems protected under the EU can easily recover after fire disturbances. Boreal ecosystems were also strongly shaped by fire (Weber and Stocks 1998). Herewith, the effects of fire in the protected areas might be social and economic, if the ecosystems and plants have developed strategies of adaptation to the fire impact. The effects of fire in socio-economical spheres are substantially enhanced by the lack of plans that consider fire management.

Fire can be a good tool or a bad visitor, depending on how we deal with it. From this paradox many problems concerning fire policy have emerged. If we choose the extreme protection of protected areas, it is very likely that a probability of being visited by wildfires will be higher. On the contrary, the option of the respect for local traditions can strongly reduce this probability. This simple choice can have tremendous (great) implications for the environment and especially for economic and social conditions. Fires and their impact have to be managed and should include social, economic, cultural, and ecological variables, with the aim of minimizing the damage and maximizing the benefits (Rego et al., 2010).

\section{Fire management in Asia \\ India}

In India, Joint Forest Management (JFM) committees have been established at the village level to involve people in forest protection and conservation. At present there are 36,165 JFM committees throughout the country, covering an area of more than 10.24 million ha (Kumar, 2001). The committees also have been given responsibilities to protect the forests from fires. For this purpose, the Modern Forest Fire Control plan is being revised and JFM is being made an integral component of the forest fire prevention strategy. Use of aircraft and helicopters has not been cost effective in the fire management programme and the Air Operation Wing is being closed down. For emergency purposes, however, a provision for hiring aircraft for transporting crews and water is being maintained. The Government of India has issued national forest fire prevention and control guidelines. Salient features of the guidelines include identification of vulnerable areas on maps, creation of a data bank on forest fires, establishment of a fire forecasting system, provisions for a crisis management group, involvement of JFM committees, and efficient enforcement of legal provisions.

\section{Philippines}

The Mountain Province in the Cordillera of Luzón, Philippines, is a fire-prone area. The dipterocarp stands are 
located along creeks and rivers mostly in the eastern part of the province, particularly in the municipality of Paracelis and Natonin. Pine forests are the major forest vegetation covering 53,767 ha, while the mossy forest covers about 37,200 ha. The pine forest with its open crown and grassy understory provides high fuel loads during the dry season.

A region-wide Forest Fire Management project, implemented from 1987 to 1989 has determined that 99 percent of forest fires are caused by human activities, such as slash-and-burn agriculture (kaingin), debris and garbage burning, arson, and other indiscriminate use of fire. This situation gave rise to the "No Fire Bonus Plan", which intends to involve local people in fire prevention (Pogeyed, 1998). To motivate and encourage participation in the implementation of forest conservation/protection measures against fires, the programme's goals are to:

- organize and strengthen community members to enable them to work towards a common endeavour;

- strengthen the political will of the community and the Local Government Units towards the conservation/protection of the forest resource; and

- incorporate forest conservation/protection initiatives into development efforts at the community level.

To achieve these goals, the specific objectives are set as follows:

- limit/prevent, if not totally eradicate, the occurrence of forest wildfires in every community (barangay) of the province;

- regulate the use of fire by farmers through the issuance of permits to burn;

- monitor and record the occurrences of fire in each barangay regularly; and

- continuously investigate the causes of fires and recommend policies to concerned agencies for implementation.

Part of the implementation strategy is to mobilize all barangay communities to participate in the No Fire Bonus Plan. The provincial government of Mountain Province will establish a committee to select barangays for the plan and to facilitate the awarding of projects to winning barangays. Participating barangays that have not incurred any forest fire during the dry season or other forest destruction, such as illegal logging and occupation in forestlands, shall be awarded development projects worth 200,000 pesos (about US\$4,000). The programme shall adopt a community-based approach in identification, planning and implementation projects. The projects shall include, but not be limited to, environment-related activities such as garbage disposal, water impounding schemes and erosion control. A total of 124 barangays from the municipalities of Barlig, Bauko, Besao, Bontoc, Sabangan, Sadanga, Sagada and Tadian have been proposed as the beneficiaries of this programme (Pogeyed, 1998).

\section{Fire management in Africa}

The majority of wildfires in developing countries of the tropics and subtropics, and in temperate regions are caused by human activities usually associated with land-use practices and changes. The property, health and welfare of people in these areas are negatively affected by direct and indirect consequences of fire and air pollution. Active involvement of the local people has therefore been recognized as a condition for the successful implementation of fire management programmes (Johann et.al, 2002). The organizational arrangements and procedures of national and local fire management systems vary from country to country. In the following sections examples are given from Namibia, Zambia and South Africa.

\section{Namibia}

In 1996, the Forestry Department of the Ministry of Environment and Tourism selected East Caprivi Region (north-eastern Namibia) as the pilot area for the NFFP to develop a model for community based forest fire control (Kamminga, 2001). The pilot area consists of 1.2 million ha of Namibia's best forest resources and belongs to the sub-tropical region. Most of the area is communal land, but a significant part is state forest, national park and wildlife conservation area.

Although the pilot area falls within the Kalahari sand zone, the forests are moderately productive because of the relatively high rainfall $(700 \mathrm{~mm})$. Prior to the beginning of the project, $70-80$ percent of woodlands in the pilot region used to burn each year and almost all fires were anthropogenic in nature (Johann et.al, 2002). NFFP was launched on basis of the 1996 Namibia Forestry Strategic Plan. The first phase was implemented from 1997 to 2001. The fire component, "Pilot Project for Forest Fire Control", was modified to IFFM in 1998 to emphasize that fire is a suitable land management tool, if carefully timed and used (Goldammer, 2001). One objective of the IFFM was to assist the government in formulating a national fire policy and regional fire management plan for East Caprivi. The main objective according to the project document, however, was "the implementation of an applicable model for integrated forest fire management, implemented by Namibians". The major outputs included:

- improved efficiency and effectiveness of the Directorate of Forestry (DoF) and other agencies and stakeholders implementing applicable IFFM activities in the field.

- development of national guidelines and forest fire policy. 
- changed attitudes and behaviour of general public towards the use of fire and burning, and its detrimental effects to the environment in Caprivi.

IFFM adopted the following strategies:

- $\quad$ support for public relations and extension activities for forest fire prevention within the government.

- at the community level, training and mobilisation of community members towards improved fire control and subsidised cutline construction and maintenance.

- organization of a massive fire awareness and public education campaign through schools and local organizations in the area, involving all stakeholders. This included the production and use of written materials, posters, billboards, drama, radio programmes and videos (Johann et.al, 2002).

An interim (short-term) evaluation in 1998 concluded that the results of creating a model for controlling fires in communal lands in Caprivi were encouraging (Table 1).

Table 1: Performance indicators of activities in East Caprivi between 1995 and 1998*

\begin{tabular}{|c|c|c|c|c|}
\hline \multirow[t]{2}{*}{ Output areas } & Conventional & \multicolumn{3}{|c|}{ Implementation of IFFM } \\
\hline & 1995 & 1996 & 1997 & 1998 \\
\hline Total area burned (ha) & 838,000 & 790,000 & 558,000 & 390,000 \\
\hline Area under forest fire management (ha) & 10,000 & 115,000 & 115,000 & 636,000 \\
\hline Area protected from fire by DoF (ha) & 2,000 & - & - & - \\
\hline $\begin{array}{l}\text { Area protected from fire by local } \\
\text { communities (ha) }\end{array}$ & 0 & 50,000 & 202,000 & 450,000 \\
\hline $\begin{array}{l}\text { Effectiveness of fire prevention in } \\
\text { managed areas }(\%)\end{array}$ & 20 & 44 & 51 & 71 \\
\hline
\end{tabular}

Source: Johann et.al., 2002

The programme has involved many local people, their participation varying from attending drama shows, learning how to fight fires, determining the locations of cutlines, to being employees constructing or maintaining cutlines. These efforts saw a 54 percent reduction of burned areas annually in the area and also a decrease of fire incidences by 70 percent. During the high-risk fire season (April-November) in 1999, about 1,500 villagers were engaged in controlling wildfires in northeastern Namibia. In addition, some 1,000 teachers and 30,000 students received basic fire education. In 1998, a survey examining local people's experiences in controlling fires in their communities showed that the positive effects of better fire control on the natural resource base were widely recognized (Virtanen, 1998), as can be affirmed by:

$>$ improved condition of plants and trees;

$>$ more forest products (e.g. fruits, nuts) as food supplements;

$>$ increased numbers of wildlife;

$>$ increased availability of grasses, thatch and other building materials;

The Namibian administration has forbidden the use of fire and this is still the situation today. The new Draft Forest Bill, however, delegates fire management responsibilities and authority to the traditional authorities. This will hopefully empower the local communities to assume ownership over fire control and management, a crucial factor for the sustainability of IFFM activities.

\section{National Guidelines on Forest Fire Management in Namibia}

After an earlier proposal to call a National Round Table (Discussion) on Fire Management and in accordance with the recommendations of the Round Table in 1999 (Goldammer, 2001), the IFFM assisted the government to prepare the National Guidelines on Forest Fire Management (Jurvélius, 2001). The guidelines strongly encouraged community participation in forest fire protection programmes.

\section{Zambia}

Widespread and uncontrolled burning is common during the dry season in the Western Province of Zambia, destroying large areas of rangelands, woodlands and forests. Some fires are started deliberately by livestock owners seeking to promote a green flush for their animals, by rodent hunters clearing vegetation to catch their prey more easily, by people creating firebreaks around their homesteads or seeking to improve visibility, or by individuals playing with fire. The fires are also ignited by people clearing land for cultivation, smoking out beehives, or by people making charcoal (Frost, 1992a).

Whereas the lowlands seem to be able to sustain regular burning, many of the woodlands are beginning to show signs of damage from too frequent and intense fires. This is exacerbated by timber extraction, which is opening up the woodland canopy and allowing more light to reach the herbaceous layer, thereby promoting increased production of grass and shrubs that fuel the fires. Fires kill the more fire-sensitive trees and suppress the regrowth of the more resistant species. This is preventing the re-establishment of the woodland canopy, 
which would suppress herbaceous production and reduce fuel loads, fire frequency and intensity (Gambiza et al., 2000). Besides being illegal, the widespread and uncontrolled use of fire poses a number of potential problems for resource managers. For example, shortages of fodder for livestock towards the end of the dry season may more than offset any benefits derived from having access to smaller amounts of higher quality forage. Progressive declines in woodland cover and productivity, destruction of timber, fuel wood, thatching grass and other resources on which many people of the Western Province depend are other issues to be considered (Frost, 1992b).

To satisfy divergent needs, conflicting objectives have to be considered (e.g. burning may improve fodder quality but is also likely to diminish the availability of thatch grass and timber). Any attempt to institute controlled burning within a community needs to be broad-based and address the reasons why people use fire, the benefits to be gained through its use and the consequences of changing the pattern of use. In short, a strategy for prescribed burning had to be developed within a broader land-use and resource-management programme. Prescribed burning requires decisions on where, when and how to burn, what preparations are needed to control the fire, and co-ordinated actions to control the spread of the fire. Co-operative management of the post-fire regrowth is equally important. Burning for the production of high quality fodder should be confined to vegetation types, mostly the lowland moist grasslands, where sustained dry season regrowth of the grasses could be expected, even when grazed (Paulo Pereira et.al., 2012).

The RMT initiated a series of district-level workshops between December 1993 and June 1994to promote the revised policy and to recommend an action plan. Workshops were held in five of the six districts of the province (Sesheke, Senanga, Kaoma, Lukulu and Kalabo). Although the workshops were initiated by the RMT, the meetings were officially held under theauspices of the local district council and chaired by the council chairman. Workshop participants included district councilors, members and representatives of the Barotse Royal Establishment, farmers, local officials of government departments, and other interested parties. There was general agreement at the workshops that current burning practices were not beneficial because vegetation was destroyed, resulting in the loss of natural resources and exposed soil that is prone to erosion. These negative effects were blamed on uncontrolled and uncoordinated burning, coupled with the fire users' lack of technical knowledge. All the workshops strongly recommended greater community involvement through their traditional leaders, together with government officials such as Natural Resources and Forestry Officers, in decisions on the use and control of fire. Responsibility for controlling burning used to be vested in traditional leaders (e.g. chiefs, indunas, and headmen). Violators of the local laws were prosecuted in traditional courts. Current legislation makes no direct provision for community control (Johann et.al., 2002).

Resource management entails considerable costs that may become onerous for poor rural people.

In general, they only invest in natural resource management if they expect clear improvement intheir livelihoods or if it will reverse a situation that threatens their livelihoods. Experience elsewhere in southern Africa suggests that for community-based natural resource management institutions to be both functional and robust, they need to fulfill most of the following criteria (Murphree, 1991):

$>$ those who manage the resources must have a vested interest in the outcome. This means that the resource managers must be the landholders and primary beneficiaries.

$>$ there must be a close and proportional link between management inputs and benefits.

$>$ the benefits must be tangible and immediate.

$>$ there should be local autonomy in decision-making, both in regard to management and the distribution of benefits.

$>$ the resource user group should be small enough to be cohesive and to lower transaction costs, but not so small that it becomes exclusive and wholly self-serving.

$>\quad$ the leadership must be accountable, transparent and broadly representative of the community it serves.

$>$ responsibility at different scales should be nested to give effect to the principle of subsidiary.

$>$ the boundaries of the management units should be distinct and exclusive (although this requirement may be difficult to implement because there is often considerable overlap between adjacent communities in the areas from which they obtain common-pool resources).

$>$ political and administrative boundaries of these management units should coincide broadly with the biophysical ones.

\section{South Africa: Ukuvuka: Operation Fire Stop Campaign}

Crisis can lead to dramatic reactions, encouraging people to co-operate in new and creative ways. Asshocked residents of the Western Cape Province, South Africa, watched their mountains burn in January 2000, the thought in every mind was that something urgent had to be done to prevent such devastation from occurring again. Their response was speedy, dynamic and powerful. People shared a vision of maximum fire protection and restored ecological integrity, giving their time willingly to translate this vision into a business plan that would find resources and co-ordinate how various authorities would act (Kruger, 2001). The aptly named 
"Ukuvuka: Operation Fire stop Campaign"(Ukuvukais a Xhosa word meaning "to wake up") brings together representatives of government, private enterprise and the media in a partnership unprecedented in South Africa. Public sector members of the initiative include Working for Water Programme representing the national government, the Western Cape Government, South Africa (SA) National Parks, the South Peninsula Municipality, the City of Cape Town and the Cape Metropolitan Council that has committed Rand (R) 30 million to the Campaign. Other public sector organizations are contributing staff support and expertise. Major private sector funds have come from Santam (with R20 million, believed to be the largest single donation ever made to a South African environmental project), Cape Argus (R5.5 million), Nedbank (R5 million) and Total (R4 million). In addition, local companies and the World Wide Fund for Nature (WWF) South Africa have offered free services, ranging from the production of advertising materials to legal assistance (Johann et.al., 2002).

The Campaign has a four-year mandate, started in February 2000, to achieve its goals. It places great emphasis on an effective communication and education progrmme, and an accountable administration. The Campaign hopes to be a role model for similar projects elsewhere in the country by passing on lessons learned (Kruger, 2001).

\section{Fire in National Parks of Ethiopian}

After the large forest fires in Ethiopia in 2000 and the successful international response to the emergency (Goldammer, 2000), the government called for a National Round Table on Fire Management in September 2000. It was recognized that Ethiopia, currently a country without any fire management capacities, would build its future programme on the basis of community involvement (Ministry of Agriculture, 2001).

\section{Threats of Bale Mountains National Park and Actions Undertaken}

The Bale Mountains National Park (BMNP) is one of the protected areas in southeastern Ethiopia with the largest areas of continuous Afroalpine and Afromontane forest habitats in Africa. The park was established in 1970 containing an area of 240,000 hectares in the Bale massif. It was established by the Ethiopian Wildlife Conservation Organization (EWCO) with the primary objective of conserving the wildlife (endemic species like the Mountain Nyala (Tragelaphusbuxtoni) and the Ethiopian wolf (Canissimensis) and other valuable natural resources in the area (Anteneh and Temesgen, 2009). It protects a broad range of habitats from 1,500 $\mathrm{m}$ asl in moist montane forest and ericaceous shrub land to $4370 \mathrm{~m}$ asl in Afro-alpine habitat on the Sanetti plateau (Alers et al., 2007). It is one of the 34 conservation international biodiversity hotspots and qualified for world heritage site and biosphere reserve listing (Anteneh and Temesgen, 2009).

The BMNP supports high levels of species richness and endemism (OFWE et al., 2014). To date, 78 mammal species have been recorded in BMNP, of which 22 of these mammals are endemic to Ethiopia (Alers et al., 2007). From the total endemic mammals recorded in the Ethiopian highlands, $67 \%$ are endemic to the Bale Mountains. This is by far the highest proportion of endemics (OFWE et al., 2014). In addition, 278 bird species have been recorded; 16 birds are Ethiopian endemics (Alers et al., 2007). 57\% of Ethiopia's endemic birds are found in the Bale Mountains.

In spite of its huge potential and importance, ecological degradation is rapid and poses a severe threat to the survival of most of these species (Farm Africa, 2008). In BMNP, there is rapid village expansion in and around the park (Jacobs and Schloeder, 2001). Parallel to village expansion, agricultural lands are expanding, forests are being destroyed, overgrazing is overwhelming and forest fire is recurrent (ETFF, 2007). If conservation efforts are not successful and people continue to exploit the resources in an unsustainable way, more species of mammals would go extinct than any area of equivalent size on the globe (OFWE et al., 2014).

\section{Fire Damage in BMNP}

There are recurrent fires in the Bale mountains massif. However, the forest fire that occurs between February and April 2000 is the most sever. This fire destroyed more than 90,000 ha of the country's moist evergreen forest in the Bale Zone alone, which was the worst fire of the past one hundred years. The forest fire occurred in 2008 was recorded as the second severe fire next to the 2000 forest fire. It was occurred in about nine Weredas of the Bale Zone. Five of them among the nine are the major Weredas in which forest fire was out of control. These Weredas are Goba, Dinsho, DaloMana, Adaba and HarennaBuluq. The BMNP lies within these five Weredas and it is this park which was severely affected. The total forest loss in the five Weredas is 11,947 ha (Table 2) (Anteneh and Temesgen, 2009). The causes of fire in BMNP are anthropogenic in which farmer's set fire for various activities: honey collection, agricultural land preparation, improved forage quality, and reduce suspected livestock predators such as Leopards, Pantherapardus, spotted hyenas and Crocutacrocuta (Alers et al., 2007; Vial, 2010) 


\section{FACTORS THAT UNDERMINE CONSERVATION}

\section{$>$ Lack of specific legislation and policy concerning BMNP}

BMNP falls under the jurisdiction of the Oromia state government, with day-to-day management under the Oromia Rural Land and Natural Resources Administration Authority (Alers et al., 2007). However, forests, grasslands and water are treated as open access resources in spite of the paper policies and theoretically regulated land management systems (Farm Africa, 2008).

\section{$>$ Timber and firewood harvesting}

In association with settlement and agricultural expansion,demand for timber and wood in BMNP has increased both locally and commercially (Vial, 2010). The problem was devastative since the 1974 land reform followed by immigration and agricultural expansion, which has caused large scale forest destruction and land clearance. This pattern continues today, especially in the southern lower-level forests (Alers et al., 2007).

\section{$>$ Complex institutional arrangements}

There are various stakeholders in BMNP, including local communities, Oromia state government, Ethiopian Wildlife Authority, National Biodiversity Institute, NGOs, etc. However, the various stakeholders from state government to project implementers lack cohesion. They design to achieve different objectives. Such differences are common when conservation activities are linked to donor funding for development (Alers et al., 2007). These differences complicated the management of the park.

\section{$>$ Inadequate collaboration among development projects}

It is possible to operate development projects in BMNP like several projects operating in the vicinity of the country. However, such linkages have not been created. For example, projects to improve the livelihoods of local community in and around the BMNP and projects to conserve biodiversity of the park should have a common message of conserving the park resources. If a project concerning to improve the livelihoods of the community is at the expense of the park resources, it is very problematic for the future status of the park. This undermines conservation which further enhancing ecological degradation of BMNP (Alers et al., 2007).

\section{The Suggested Actions to be taken to Prevent Damages in the BMNP}

The Oromia regional government has invested in conservation and development initiatives in the Bale Mountains in response to the adverse and imminent threats. The innervations are mainly focused on improving the management and conservation of BMNP and conserving the unique ecosystems and wildlife of the area. The new intervention program in 2003, however, has been evolving with a focus on expanding conservation and development initiatives, bringing local communities into a central role in sustainable natural resource management, and building sustainable natural resource based livelihoods (Farm Africa, 2008). Nevertheless, they are less effective in conserving the park, and degradation of resources is continuing (Alers et al., 2007; ETFF, 2007; Anteneh and Temesgen, 2009). Therefore, some of the solutions for BMNP are listed and discussed below.

\section{* Awareness Rising}

Awareness rising should be the first action for protected area conservation. The local communities should be aware of the environmental, social and economic importance of protected areas. For example, the establishment of the BMNP is important for soil erosion control, gettingreliable rainfall and others (Anteneh et al., 2014). In addition, it is also important for the local community as a source of medicinal plants (Alers et al., 2007). In this way, awareness creations help to reduce cutting trees. This also results in the increase in numbers of wild animals especially Mountain Nyala, which in turn increases economic returns through the development of tourism in the area. Therefore, awareness creation should be applied before the establishment of any protected area.

\section{* Promoting community involvement}

The community at BMNP is participating in fire protection and wildlife, vaccination of domestic dogs, repairing fences and providing information about illegal activities found in the park. However, they are not involved with the park planning and management decisions. It is obvious that the local communities are directly affected by the establishment of the park more than any other group. Therefore, it is believed that resource managements are effective when local people are involved in all phases of the management process from planning to implementation stage (Anteneh et al., 2014).

\section{* Linking conservation activity with livelihood improvement through ecotourism}

Ecotourism is a holistic conservation approach that integrates conservation of protected areas and improving the livelihoods of communities. The local community in and around BMNP are indulged off-farming activities besides cultivation and rearing of animals. These include, tour guiding, horse rental service and selling handicraft trade. In this case, ecotourism is not only helpful in local environment protection but also plays an important role in transforming local community views towards sustainable use of natural resources as they derive direct monetary benefits out of ecotourism. Protected areas are biodiversity conservation centers and major tourism assets for a nation, particularly for developing countries like Ethiopia through providing sustainable 
benefit to the local community while supporting for the maintenance and rehabilitation of the protected areas themselves. Therefore, advocating ecotourism in an extensive manner is appropriate to improve the livelihoods of the community and to conserve the park (Demeke and Verma, 2013).

\section{Human Induced Threats in Simien Mountains National Park}

Ethiopia has the largest extent of afro alpine and sub-afro-alpine habitats in Africa. One of the major protected areas of the country that was set aside since four decades ago to conserve the afro-alpine habitats and their unique flora and fauna is the Simien Mountains National Park (SMNP). It is a home to a number of threatened and endemic species of which the Walia ibex and the Ethiopian wolf are listed as critically endangered. Taking its outstanding value and the unique features into account, the park was inscribed on World Heritage List in 1978 . The inscription was made on the basis of its importance for biodiversity and its exceptional natural beauty. However, the park has been under serious threat from expansion of settlement and cultivation, overgrazing, deforestation and associated perturbation. These anthropogenic pressures resulted in deterioration of the park habitats in general and decline of populations of flagship species, particularly the Walia ibex and Ethiopian wolf (Ethiopian Wildlife Conservation Authority (EWCA, 2014)).

\section{What remedial actions are taken?}

Based on the report from UNESCO's monitoring mission, the World Heritage Committee at its 20th session in 1996 decided to include the property on the List of World Heritage in Danger.

The World Heritage Committee adopted the following bench marks to guide a release the park from the "List of World Heritage in Danger".

The bench marks include:

1. Readjustment of the park's boundary to exclude the villages along the boundary;

2. Extension of the park to include at least Mesarerya and Limalimo Wildlife Reseves;

3. Significant and sustainable reduction in the human population density within the park, especially within the core area;

4. Effective conservation within the extended national park of a larger Walia ibex and Ethiopian wolf.

Later in February 2005, the state party report announced that considerable progress was being achieved towards addressing 3 of the 4 benchmarks but that it was unable to accomplish the bench referring to the reduction of human occupation within the property. As a result of the ensuing considerations, the state requested international assistance from UNESCO's World Heritage Fund for developing a strategy for alternative livelihood options for the population in and outside of the park. The issue of settlement extensions within the park dates back to the time of its creation, as several villages with land used for agriculture and livestock grazing were included in the protected area. This problem remained unresolved since the realignment of the park boundary which resulted in the exclusion of numerous villages from the park and, thus, an important reduction in the number of poverty stricken people residing inside the park. According to the rapid assessment carried out in October 2007, 586 households were found to be located inside the park (totaling to 3173 people), whilst 1477 households living in its immediate vicinity are cultivating plots inside the park. The total area under cultivation in the park was estimated at 2,281 ha (EWCA, 2014).

In fact, progressive measures have been taken in alleviating problems associated with livelihood of the local people and the state party has been committed to resettle the villages situated in the park in which a successful effort to 2008 with the relocation of 167 households at Arkuasiye village outside the corridor and provision of alternative livelihoods for the resettles'. However, the proposed livelihood improvement and resettlement programs have not been completed due to financial constraints. Recent assessments indicate that the program entails a significant amount of money and involvement of all development partners and stakeholders. Even though it is believed that further revision of the document needs to be undertaken, the project proposal developed for both the livelihood and settlement study documents points out that the whole program requires more than 16 million USD. From the situation on the ground, however, we can logically imagine that less amount of the proposed budget even half of it can assist a lot in creating alternative livelihood options and relocation for the community living inside the park and ensuring sound conservation of the World Heritage property (EWCA, 2014).

\section{Conclusions and outlook}

A number of projects representing a broad range of social, economic and environmental conditions have been reviewed in this paper to introduce IFFM/CBFFM projects or approaches. In some countries, the involvement of communities in fire management is well established. In others, recent project proposals have defined approaches that are specifically designed to meet local conditions. Clearly, there are many forms and degrees of community involvement. Despite many socio-cultural differences, it seems that the basic principles of community participation are rather similar throughout the various regions. 
When participation consists mainly of providing paid labor, the sustainability of such systems is fully dependent on continuous external funds. This is a problem for many countries. IFFM/CBFFM approaches that build upon existing social structures and involve traditional leadership may be less dependent on such financial support and therefore are likely to be more socially and economically sustainable. However, creating an enabling environment (e.g. appropriate changes in legislation) and awareness raising and extension support will always be required.

Despite the experiences in IFFM/CBFFM, further understanding of the concept of community participation and inter-cultural exchanges of experience and practices are necessary. The process of international co-operation in IFFM/CBFFM will hopefully help to stimulate this development.

To promote the IFFM/CBFFM approach, the GFMC jointly with the UN International Strategy for Disaster Reduction (ISDR) prepared the UN 2000 World Disaster Reduction Campaign that addressed community participation in fire management (ISDR, 2000). An international concerted

programme in conjunction with IUCN/WWF Firefight and an earlier Global Environment Facility(GEF) proposal by the GFMC that will consequently follow up the concept of fire disaster reduction through community involvement is highly recommended.

\section{References}

Alers M., Bov arnick A., Boyle T., Mackinnon K. and Sobrevila C. (2007). Reducing threats to protected areas. A Joint UNDP and World Bank GEF Lessons Learned study. p. 84.

Alexander, M. (2008. Management planning for nature conservation. Springer Science 314 p. http://dx.doi.org/10.1007/978-1-4020-6581-1

Anteneh B. and Temesgen Y. (2009). Extensive forest fire of 2007/2008 in the Bale Mountains National Park of southeast Ethiopia. Proceding of a workshop. Occeasional report No. 2/2009. 47-76pp.

Anteneh G., Melaku B. and Teshale W. (2014). Natural resource use conflicts in Bale Mountains National Park, Southeast Ethiopia. Int. J.Biodiver. Conser. 6(12):814-822.

Cole, D.N.( 2008). Wilderness, protected areas and climate change. U.S. Department of agriculture, Forest service, Climate change resource centre. Available in (http://www.fs.fed.us/ccrc/topics/wilderness.shtml)

Delong, S.C. and Tanner, D. (1996). Managing the pattern of forest harvest: lesson form wildfire, Biodiversity and Conservation, 1191- 1205.http://dx.doi.org/10.1007/BF00051571

Demeke A. and Verma A. (2013). Ecotourism for environmental conservation and community livelihoods, the case of the Bale Mountain National Park, Ethiopia.J.Environ.Sci. 2(8):250-259.

Dudley, N. (2008). Guidelines to applying Protected Area Management Categories, Gland, Switzerland, p. 86. http://dx.doi.org/10.2305/IUCN.CH.2008.PAPS.2.en

EWCA (Ethiopian Wildlife Conservation Authority) (EWCA, 2014). First Enhancing our Heritage Assessment at Simien Mountains National Park (SMNP), WHS.

European Commission (2008). Life and Europe's grassland. Restoring a forgotten hábitat, Luxembourg: Office for Official Publications of the European Communities, p. 56.

FAO (2005). Grasslands of the world, Plant Production and Protection Series No. 34, p. 514

Frost P.G.H. (1992b). A policy framework for fire management in the Western Province of Zambia.LDP, DVTCS, Department of Agriculture, Mongu, Zambia.

Goldammer J.G. (2001). Namibia Round Table on Fire, Windhoek, 10-11 November 1999. International Forest Fire News No. 25: 57-72.

ETFF (Ethiopian Tree Fund Foundation) (2007). Ethiopian Tree Fund Foundation: Promoting ETFF and tree planting event in the Bale Mountains, Southeast Ethiopia.

Farm Africa (2008). Bale Mountains Eco-Region Sustainable Development Plan Report on Phase I and II Planning Workshops in Goba, Bale 15-17 September 2008 (Phase I) and 25-26 November 2008 (Phase II). p. 29.

Frost, P.G.H. (1992a). A draft policy for fire management in the rangelands of the Western Province of Zambia. LDP, DVTCS, Department of Agriculture, Mongu, Zambia.

Gambiza, J., Bond, W., Frost, P.G.H. \& Higgins, S. (2000). A simulation model of miombo woodland dynamics under different management regimes. Ecological Economics 33: 353-368.

Goldammer, J.G. (2000). The Ethiopia fire emergency between February and April 2000. International Forest Fire News No. 22: 2-8.

Hockings, M., Stolton, S., Leverington, F and Courrau, J. (2006). Evaluating effectiveness: A framework for assessing management effectiveness of protected areas. Cambridge, $\left(2^{\text {nd }}\right)$ Edition, p. 105. http://dx.doi.org/10.2305/IUCN.CH.

ISDR (UN International Strategy for Disaster Reduction) (2000). Disaster prevention, education and youth. The specific case of wildfires. UN 2000 World Disaster Reduction Campaign. Educational kit produced by UN ISDR, Geneva - San José. 
Jacobs MJ. and Schloeder CA (2001). Impacts of conflict on biodiversity and protected areas in Ethiopia, washington, d.c, biodiversity support program.

Jurvélius, M. (2001). National guidelines on forest fire management in Namibia. Final draft, 31 March 2001. Namibia-Finland Forestry Programme. International Forest Fire News No. 25: 73-102.

Kamminga, E.M. (2001). Impact of the Integrated Forest Fire Management Program on rural livelihoods in East Caprivi Region, Namibia. Namibia-Finland Forestry Program, March 2001. Also published in International Forest Fire News No. 25: 39-57.

Kruger, T. (2001). Santam/Cape Argus Ukuvuka Operation Firestop. International Forest Fire News No. 25 : $111-114$

Kumar, C. (2001). Community involvement in forest fire prevention and control: lessons from Joint Forest Management (JFM), India. International Forest Fire News No. 26: 28-31.

Martell, D.L. (2007). Forest fire management, current practices and new challenges for operational researchers. Handbook of operations research in natural resources, International Series in Operations Research \& Management Science, 99(3), 419-509. http://dx.doi.org/10.1139/X07-210

McKenzie, D.( 2010). The effects of climate change and wild land fires on air quality in national parks and wilderness areas, Fire Management Today, 70(1), 26-28.

Ministry of Agriculture (Ethiopia) with GTZ and GFMC. (eds.). (2001). Proceedings, Round Table Conference on Integrated Forest Fire Management in Ethiopia, 19-20 September 2000, Addis Ababa, Ethiopia. Ministry of Agriculture, Addis Ababa, Ethiopia.

Moya, D., De las Heras, J., Ferrandis, P., Herranz, J.M. and Martinez-Sanchez, J. (2011). Fire resistance and forest regeneration in Mediterranean fire phrone-areas, Technology and Knowledge Transfer e-bulletin, 2(3), P. 1-5.

Murphree, M.W. (1991). Communities as institutions for resource management. CASS Occasional Paper NRM. Centre for Applied Social Studies, University of Zimbabwe.

Nolte, C., Leverington, F., Kettner, A., Marr, M. and Nielsen, G. (2010). Protected area management effectiveness assessment in Europe. A review of application, methods and results, BfN-Skripten, Bonn, p. 69.

OFWE (Oromia Forest and Wildlife Enterprise), Farm Africa and SOS Sahel Ethiopia (2014). Bale Mountains Eco-region Reduction of Emission from Deforestation and Forest Degradation (REDD+) Project- Ethiopia. p.14.

Pausas, J.G. and Keeley J.E. (2009). A Burning Story: The role of fire in the history of life, Bioscience, 59(7), P. 593-601. http://dx.doi.org/10.1525/bio.59.7.10

Pereira, P. and (2009). Braga, R. Sustainable use of protected areas: The example of the Albufeira Coastal Lagoon (Portugal), Darnaus vysymosi strategija ir praktika, 1(3), P. 111-125.

Pogeyed, M. (1998). The Philippines. No Fire Bonus Plan Program of Mountain Province. International Forest Fire News No. 18: 52-56

Rego, F., Rigolot, E., Fernandes, P., Montiel, C. and Sande Silva, J. (2010). Towards Integrated Fire Management, European Forest Institute, Joensuu, Finland.I

Synge, H. (2004). European models of good practice in protected areas, IUCN, Gland, Switzerland, and Cambridge, UK, p. 32.

Vial F. (2010). Conservation science for common ground: developing the necessary tools to manage livestock grazing pressure in Bale Mountains National Park, Ethiopia. PhD Thesis.University of Glasgow.

Virtanen, K. (1998). Survey on attitudes to forest fires: East Caprivi, Namibia, MSc thesis, University of Wolverhampton, Wolverhampton, U.K.

Weber, M.G. and Stocks, B. (1998). Forest fires and sustainability in the boreal forests of Canada, Ambio, 27(7), 545-550. 